\title{
Sedimentological Reconnaissance Survey of Kane Basin*
}

JOSEPH H. KRAVITZ and FREDRICK H. SORENSEN

U. S. Naval Oceanographic Office, Washington, D. C.

\section{Introduction}

During September 1969, Naval Oceanographic Office (NAVOCEANO) personnel aboard the USCGC SOUTHWIND (WAGB 280) conducted a survey of Kane Basin. The primary puipose of the survey was to obtain information on the composition and configuration of the Basin floor which would add to the understanding of present and past sedimentary processes in Arctic regions. This study extends the work done by NAVOCEANO and Rensselaer Polytechnic Institute in Baffin Bay during 1967 (Blee et al, 1968; Codispoti and Kravitz, 1968).

The shipboard operation consisted of bottom sediment coring and grab sampling, bathymetry, and underwater photography. Personnel from the U.S. Coast Guard Oceanographic Unit conducted temperature, salinity and oxygen measurements on 160 water samples obtained from 19 locations. Bottom sediments were obtained fxom 47 stations and 39 cores and 45 grab samples were collected. Nine successful camera lowerings resulted in several hundred photographs of the Basin floor. Over 1,000 miles $(1850 \mathrm{~km})$ of bathymetric soundings were recorded.

The ocean stations were plotted on a grid to provide sampling control; however, ice conditions precluded strict adherence to the planned grid and sometimes necessitated taking samples at considerable distances from the planned sites. Four stations near Ellesmere Island and two stations in the vicinity of Humboldt Glacier were deleted because of heavy ice. Six stations were added farther south in the area of Smith Sound. The sample locations are shown in Figure 1.

Navigation was performed with the aid of Loran $A$ and radar. It was difficult to determine precise fixes because of the problems encountered in polar navigation and the datum differences between Greenland and Canada. Even when taking into consideration frequent land sightings, it is estimated that the ship maintained an average "on station" accuracy of no better than three miles.

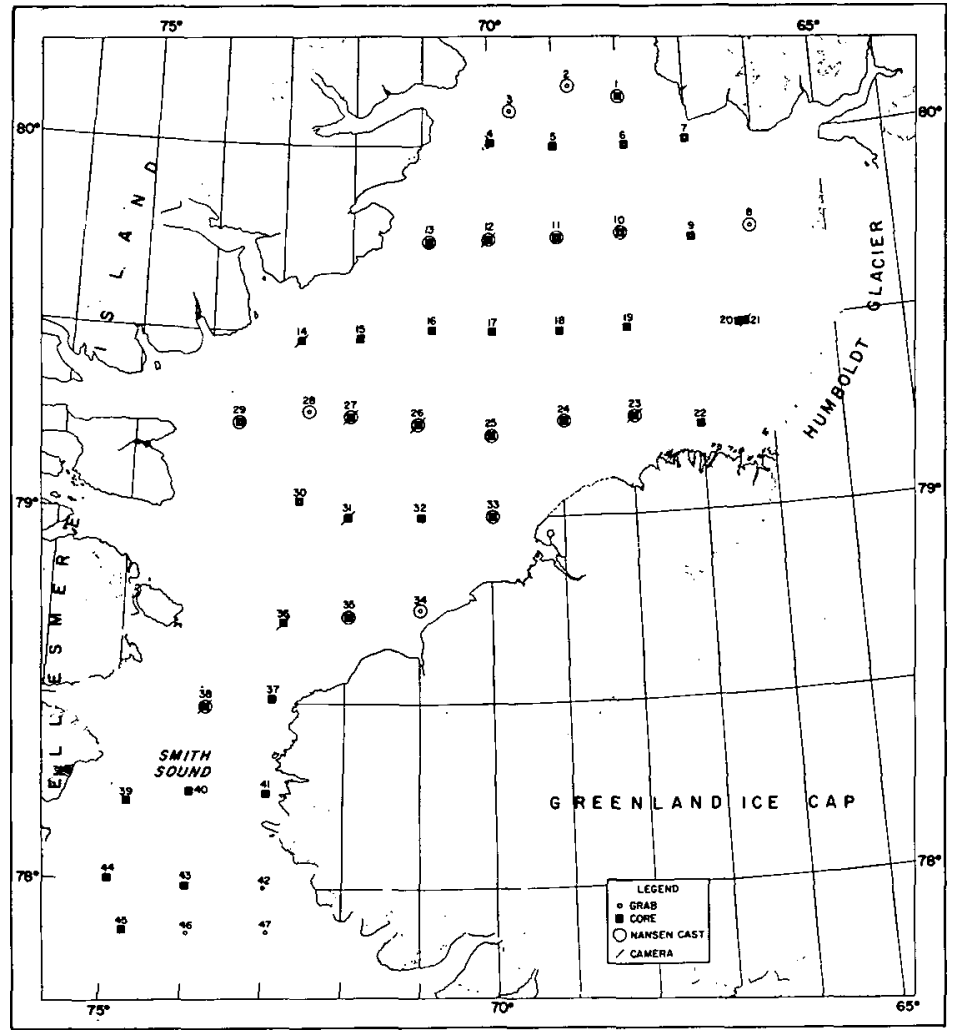

Figure 1 - Sampling stations in Kane Basin and Smith Sound.

\footnotetext{
* Manuscript received April 9, 1970.

Revised Manuscript received May 15, 1970.
} 
General Setting

Kane Basin is part of an elongated body of water known as Nares Strait. The area is bordered by northwestern Greenland on the east, by Ellesmere Island on the west, and by Kennedy Channel and Smith Sound on the north and south respectively.

The Basin has an area of approximately 27,000 square kilometres, is about 170 kilometres long and at its broadest point is 124 kilometres wide. That part of Greenland bordering Kane Basin is generally flat with a comparatively regular coastline. The Humboldt Glacier, a feature 100 metres high and $100 \mathrm{kilometres} \mathrm{long,} \mathrm{extends} \mathrm{from} \mathrm{Cape} \mathrm{Agassiz} \mathrm{in} \mathrm{the} \mathrm{south} \mathrm{to} \mathrm{Cape} \mathrm{Forbes} \mathrm{in}$ the north dividing the ice-free Greenland coastal strip in two. This glacier is presumed to be responsible for a great deal of the sediment and glacial ice found in the Basin.

The western shore of Kane Basin extends from the northwestern entrance point of Rice Strait to Cape Collinson, about $140 \mathrm{~km}$ north-northeastward, and contains many deep indentations. Seven narrow fjords generally trend in an east-west direction and penetrate inland for nearly 100 kilometres. The coast rises abruptly from sea level forming irregular mountains with talus covered bases and peaks marked by ice caps. The valleys contain many glaciers which discharge their ice into the various bays and fjords.

Approximately nine-tenths of the Ellesmere Island coastal area bordering Kane Basin is permanently ice covered. This is attributed to the cold, northerly current which causes a continuous stream of ice to build up against the Island's eastern shores. The current flowing along the Basin's Greenland coast, however, is comparatively free of ice, (except in the Humbolat Glacier area), allowing the open water to raise the general temperature. The prevailing easterly winds also carry more moisture to the western side of the Basin which is often covered with fog while at the same time there is sunshine on the Greenland coast (Arctic Pilot, 1959).

\section{Bathymetry}

The bathymetry of Kane Basin has been previously described by Pelletier (1966) and Uchupi (1964). The echogram profiles taken during the present cruise generally support the configuration described by Pelletier (1966).

The submarine topography of the Basin is characterized by two large troughs. The troughs are separated by a broad ridge which shoals from smith Sound northeastward towards Washington Land, Greenland. The eastern trough begins at the northern end of Humboldt Glacier and extends to the southwest where it gradually deepens from approximately 200 metres to over 500 metres, in the direction of Smith sound. The western trough is shoaler than its eastern counterpart and runs parallel to Ellesmere Island. The bottom of this trough is convex, being more shoal in the centre (200-300 metres) and becoming deeper at either end (300 metres). A small, narrow, fairly deep trough (400-500 metres) located along the southside of Bache Peninsula, joins the other troughs at the northern end of Smith sound.

\section{Shipboard Procedures}

Grab samples were obtained with "orange peel" type bottom samplers. The cores were collected using "modified Ewing" open barrel gravity corers with barrels 11 ft. (3.4 m) long that contained $6.35 \mathrm{~cm}$ ID polycarbonate liners. The cores were stored vertically and several layers of cushioning material were placed between them and the bottom of the boxes in an attempt to reduce the effects of the ship's vibration on the sediment.

Photographs of the sea floor were taken with a single underwater camera, (model 200A) and light source (model 2loK) manufactured by EG\&G International. The camera and light source were attached to a metal frame housing a sonic "pinger". The "pinger" emits signals which are picked up by the ship's $A N-U Q N$ receiver and passed into an oscilloscope. By monitoring the signals on the oscilloscope the distance of the camera off the bottom can be determined and controlled. The camera system was equipped with a delay unit which triggered it at a preset time. The bottom was then photographed every 12 seconds until either all the film was expended or the lowering was terminated. After each lowering several strips of film were developed to ascertain the quality of the photography and to determine whether the system was functioning properly.

The SOUTHWIND'S AN-UQN sonic depth recorder was used to take 1112 nautical miles (2060 km) of continuous sonic profiles. The recorder was operated continuously between oceanographic stations as well as on station, except during camera drops. The 0-600 foot (0-183 metres) scale was used in waters less than 100 fathoms (183 metres). The 0-600 fathoms (0-1097 metres) scale was used in all other areas. 


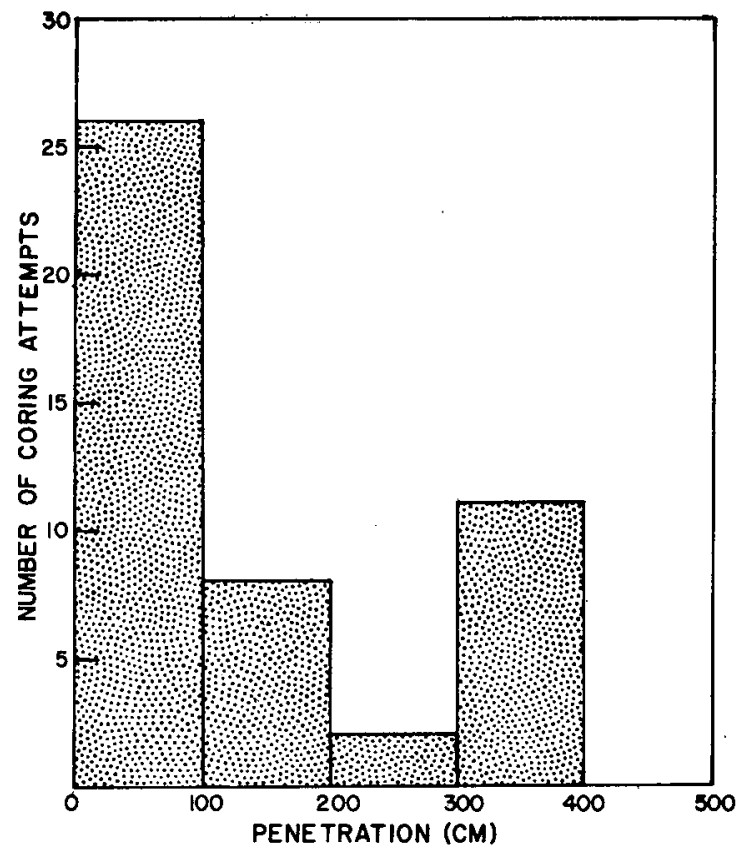

Figure 2 - Histogram depicting corer penetration.

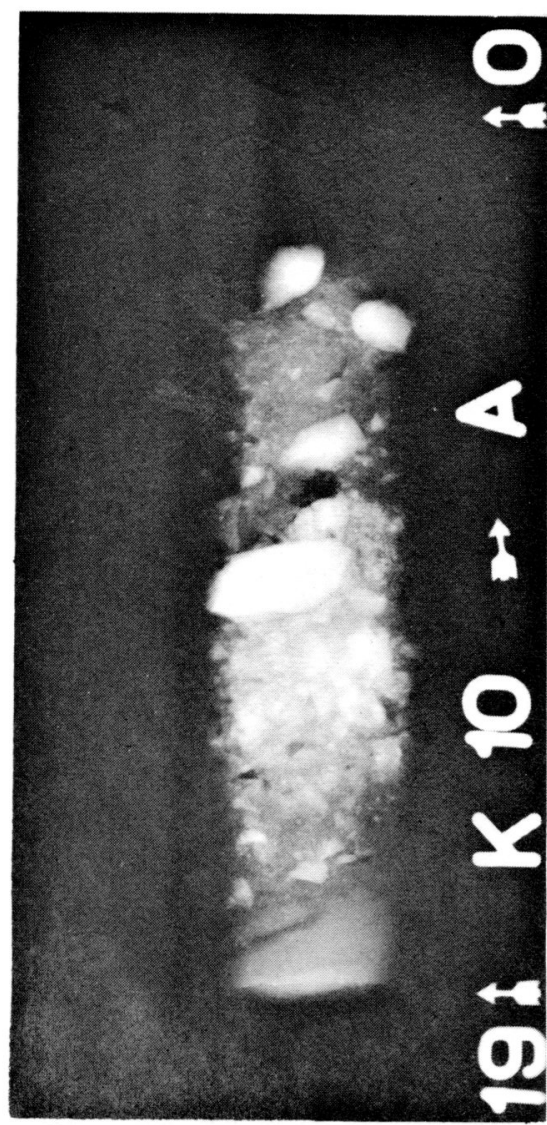

Figure 3 - Radiograph of core contoining coarse ice rafted material taken at Station 13.

\section{Laboratory Work}

In the laboratory the velocity of sound through the sediment cores was measured using an Underwater Systems Sediment Sound Velocimetre. The cores were then split longitudinally, and one half was analyzed for mass physical properties, texture, carbonate and, organic carbon. The shear strength of the sediment was determined by the fall cone method (Hansbo, 1954). The other half of the core was $x$-rayed, photographed, and put in the core repository.

Analysis of the microfossils is being undertaken by D. Shumard in the Geology Department of Baylor University. Clay mineral identification is being carried out in co-operation with Dr. D.D. Carstea of the U.S. Geological Survey, Washington, D.C.

\section{Preliminary Information}

Coring in Kane Basin proved to be a problem because of the extreme hardness of the Basin floor. Corer penetration for the 47 stations averaged $121 \mathrm{~cm}$ and ranged from 0 to $350 \mathrm{~cm}$. In 8 (17\%) of the locations the corer did not penetrate at all. Figure 2 illustrates the frequency distribution of corer penetration experienced during the survey. The $100 \mathrm{~cm}$ class intervals were selected arbitrarily.

Where no cores were recovered (zero penetration) the composition of the bottom was determined from grab samples alone. These particular samples were invariably made up of cobbles, pebbles, and coarse sand accounting for the lack of corer penetration at the sites.

When cores were recovered they all contained some coarse material. The radiograph in Figure 3 is typical of the upper few centimetres of the majority of the cores. Many of these samples had coarse constituents scattered throughout their entire length, however, the quantity and concentration of this material varied greatly. Only a few of the cores displayed marked stratification.

Most of the underwater photographs showed some form of marine life, and certain parts of the Basin contained abundant benthic fauna. Many of the rocks brought to the surface were encrusted with sessile organisms, both living and dead, such as bryozoa. 


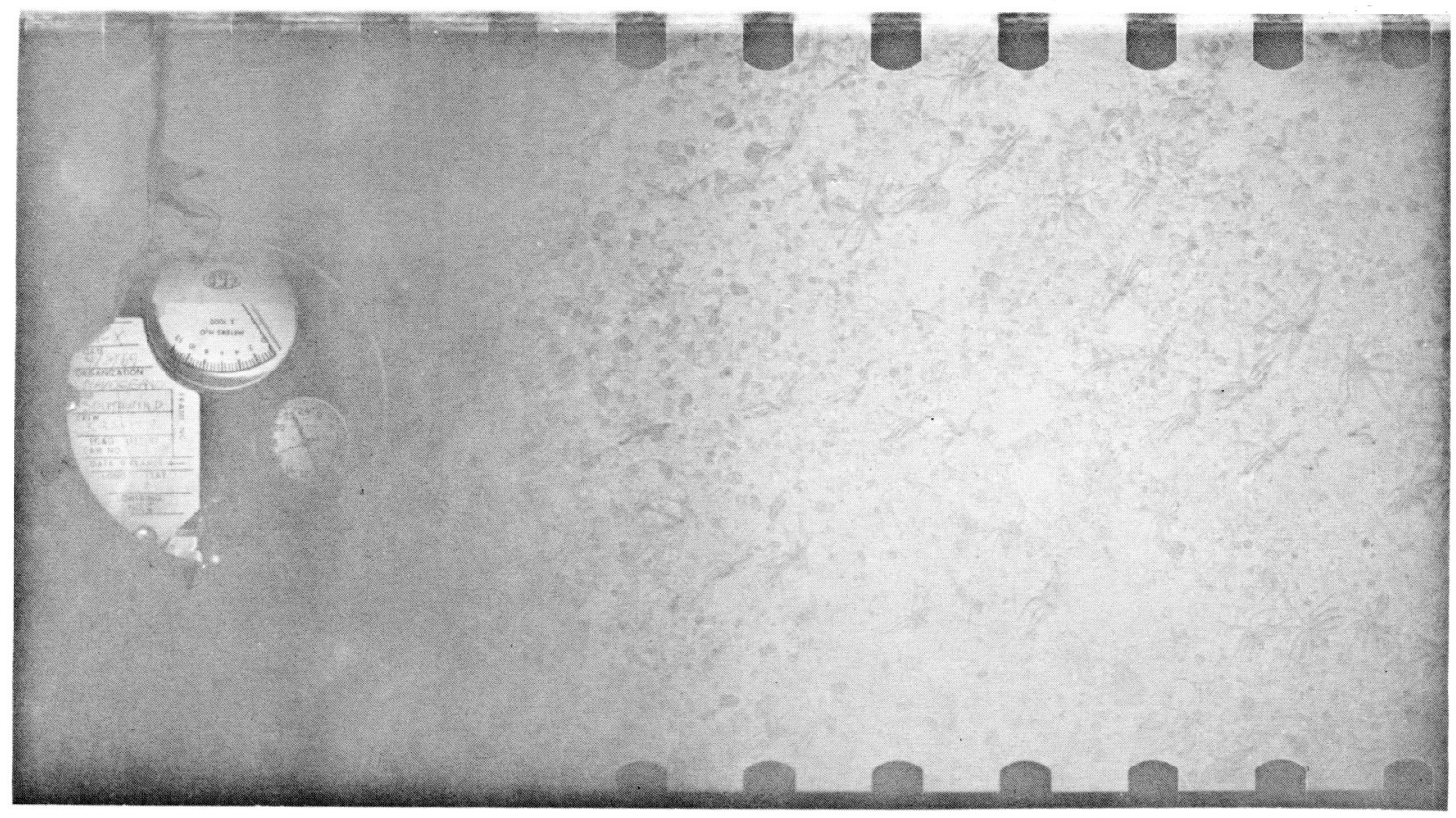

Figure 4 - Photograph of the floor of Kane Basin, Station 26, water depth 199 metres.

Figure 4 is a photograph of the Basin floor at $79^{\circ} 28.5^{\prime} \mathrm{N}$ latitude and $72^{\circ} 48^{\prime} \mathrm{W}$ longitude. At this location the bottom was strewn with coarse, poorly sorted, terrigenous material (probably ice rafted), and crinoids, ophiuroids, and echinoids were present in large numbers. Grab and core samples from the site were composed of grayish-brown sediment made up of cobbles and sand.

Based on a cursory examination of less than one-fourth of all samples taken, the following rock types have been identified; garnetiferous and granitic gneiss, quartzite, limestone, granite, slate, sandstone and coal. Limestone is the most ubiquitous rock type. These results are similar to those reported by Uchupi (1964).

The primary agent of transport and deposition affecting the most recent sediments appears to be ice rafting, with stream runoff and current activity playing lesser roles. At the present time insufficient evidence has been derived from the materials collected, to establish any definite patterns of sediment distribution.

\section{References cited}

ARCTIC PILOT, 1959, Volume III: Hydrographic Department, Admiralty, London, England.

BLEE, J.J., BAKER; S.R., and FRIEDMAN, G.M., 1968, Sedimentological survey of Baffin Bay: Maritime Sediments, v. 4, p. 4-6.

CODISPOTI, L.A., and KRAVITZ, J.H., 1968, Oceanographic cruise summary Baffin Bay - David Strait Labrador Sea, summer 1967: Naval Oceanographic Office, IR no. 68-23, 20 pp. (Informal Report).

HANSBO, S., 1957, A new approach to the determination of the shear strength of clay by the fallcone test: Royal Swedish Geotechnical Institute Proceedings, no. 8, p. 1-59.

PELLETIER, B.R., 1966, Development of submarine physiography in the Canadian Arctic and its relation to crustal movements: in Roy. Soc. Canada, Spec. Pub. No. 9 (editor G.D. Garland), p. 77-101.

UCHUPI, E., 1964, Sediments and topography of Kane Basin: Oceanographic observations Kennedy Channel, Kane Basin, Smith Sound, and Baffin Bay, U.S. Coast Guard Oceanographic Report no. 5, p. $61-72$. 